\title{
ON THE MODELING OF THE INCOME DISTRIBUTION BUSINESS CYCLE DYNAMICS
}

\author{
BURKHARD HEER
}

CESIFO WORKING PAPER NO. 1945

CATEGory 5: Fiscal Policy, Macroeconomics AND GROWTH

MARCH 2007
An electronic version of the paper may be downloaded
- from the SSRN website:
- from the RePEc website:
www.SSRN.com
Www.RePEc.org
- from the CESifo website: www.CESifo-group.de




\title{
ON THE MODELING OF THE INCOME DISTRIBUTION BUSINESS CYCLE DYNAMICS
}

\begin{abstract}
Empirically, the income share is procyclical for the low-income groups and acyclical for the top 5\%. We find that business cycle models should consider overlapping generations and elastic labor supply in order to replicate this finding.

JEL Code: C68, D31, E32.
\end{abstract}

Keywords: income distribution, business cycle, overlapping generations.

Burkhard Heer

Free University of Bolzano-Bozen

School of Economics and Management

Via Sernesi 1

39100 Bolzano

Italy

Burkhard.Heer@unibz.it

This version: March 6, 2007 


\section{Introduction}

Castañeda et al. (1998) document that the US income distribution is highly, but not perfectly procyclical for the low income quintiles, countercyclical for the top 60-95\%, and acyclical for the top 5\%. They also present a dynamic general equilibrium model with infinitely-lived agents and unemployment risk that is able to replicate the movements of the lower income quintiles. During a boom, the number of unemployed workers decreases. As a consequence, the relative income share of the lower income quintiles rises at the expense of the higher income quintiles. However, the income shares are almost perfectly correlated with output, either positively or negatively. Therefore, they also fail to replicate the income dynamics of the very rich that is acyclical.

In this paper, we present a simple business cycle model with overlapping generations and elastic labor supply in order to improve upon the modeling of the cyclical income distribution dynamics. We consider households with different productivity types. In addition, individual productivity is also age-dependent and subject to an idiosyncratic shock so that we are able to match both the observed income and wealth heterogeneity. The latter feature, of course, is important for the study of the factor income distribution dynamics. Aggregate uncertainty is introduced in the form of a shock on aggregate production technology as in Castañeda et al. (1998) .

In our model, the almost perfect correlation of the lower income quintiles with output is reduced as the high-productivity agents have a more elastic labor supply than their lowproductivity contemporanies. ${ }^{1}$ In addition, the share of the top $5 \%$ of the income earners is almost acyclical as i) many of the income-rich agents are wealth-rich retired agents and ii) the wealth-rich workers also have a less elastic labor supply than the wealth-poor workers. During an economic expansion, both wages and pensions increase. Pensions are tied to the current wage rate. However, workers increase their labor supply, which is not possible for retired workers. Therefore, the income share of workers increases and is procyclical.

The paper is organized as follows. In Section 2, we describe our model. Our results are presented in Section 3. Section 4 concludes. The computation is explained in more detail in the Appendix.

\section{The model}

Three different sectors are depicted: households, firms, and the government. Households differ with regard to their individual productivity and are also subject to idiosyncratic productivity risk. They maximize discounted life-time utility with regard to their intertemporal consumption, capital, and labor supply. Firms are competitive and maximize profits. The government provides pensions which it finances with a tax on wage income.

\footnotetext{
${ }^{1}$ Heer and Maussner (2007) show that this need not be the case in the presence of progressive income taxation.
} 


\section{$2.1 \quad$ Households}

Households live 70 periods. Periods are equal to one year. Households are born at age 1 (corresponding to real life-time age 20). Each generation is of measure $1 / 70$. The first 45 periods, they are working, the last 35 periods, they are retired and receive pensions. Households maximize expected life-time utility at age 1 in period $t$ :

$$
E_{t} \sum_{s=1}^{70} \beta^{s-1} u\left(c_{t+s-1}^{s}, l_{t+s-1}^{s}\right),
$$

where $s$ denotes age. Instantaneous utility is a function of both consumption $c$ and leisure $l$ :

$$
u(c, l)=\frac{\left(c^{\gamma} l^{1-\gamma}\right)^{1-\eta}-1}{1-\eta} .
$$

The total time endowment is equal to one and allocated between leisure $l$ and work $n$, $n+l=1$.

The worker's labor productivity $e(s, \epsilon, z)=\epsilon z e^{\bar{y}_{s}}$ depends on the agent's permanent efficiency type $\epsilon \in \mathcal{E}=\left\{\epsilon_{1}, \epsilon_{2}\right\}$, his idiosyncratic stochastic productivity $z \in \mathcal{Z}=\left\{z_{1}, z_{2}\right\}$, and his age $s \in \mathcal{S}$. This modeling of labor productivity has often been applied in DGE (dynamic general equilibrium) analysis for the following reasons: i) Differences in the permanent efficiency type $\epsilon$ help to generate the wage heterogeneity that is observed empirically. In our case, two different efficiency types are enough to achieve this aim. ii) Workers will build up precautionary savings if they face idiosyncratic productivity risk $z$. Therefore, the wealth distribution becomes more heterogenous in better accordance with reality. iii) The agedependent component $\bar{y}_{s}$ helps to explain differences in the age-income distribution that is important to explain the movement of the cross-section factor shares.

In each period $t$, an equal measure of 1 -year old workers of productivity types $e\left(1, \epsilon_{i}, z_{j}\right)$, $i=1,2, j=1,2$, is born. During working age, $s=1, \ldots, 44$, the process for idiosyncratic productivity $z_{s}$ is a Markov chain:

$$
\pi\left(z^{\prime} \mid z\right)=\operatorname{Prob}\left\{z_{s+1}=z^{\prime} \mid z_{s}=z\right\}=\left(\begin{array}{ll}
\pi_{11}^{z} & \pi_{12}^{z} \\
\pi_{21}^{z} & \pi_{22}^{z}
\end{array}\right)
$$

Depending on his efficiency type $\epsilon$, the agent receives pensions $b_{t}(\epsilon)=\epsilon \bar{b}_{t}$ in old age that are financed by a social security tax $\tau_{w, t}$ on the young workers' wage income.

Let $k, w$, and $r$ denote the individual capital stock, the wage rate and the interest rate, respectively. The working agent of age $s$ faces the following budget constraint in period $t$ :

$$
k_{t+1}^{s+1}=\left(1+r_{t}\right) k_{t}^{s}+\left(1-\tau_{w, t}\right) w_{t} e(s, \epsilon, z) n_{t}^{s}-c_{t}^{s}, \quad s=1, \ldots, 45 .
$$


The budget constraint of the retired worker is given by

$$
k_{t+1}^{s+1}=\left(1+r_{t}\right) k_{t}^{s}+b_{t}(\epsilon)-c_{t}^{s}, \quad s=46, \ldots, 70 .
$$

Agents are born without capital at age $1, k_{t}^{1} \equiv 0$, and do not work in old age, $l_{t}^{s}=1$ for $s \geq 46$. In addition, we impose a borrowing constraint with $k_{t}^{s} \geq 0$.

\section{$2.2 \quad$ Firms}

Firms are competitive and produce output using capital $K$ and labor $N$. Production $Y_{t}$ is characterized by constant returns to scale and assumed to be Cobb-Douglas:

$$
Y_{t}=A_{t} F\left(K_{t}, N_{t}\right)=A_{t} K_{t}^{\alpha} N_{t}^{1-\alpha}
$$

The aggregate technology level $A_{t} \in\left\{A_{1}, A_{2}\right\}$ follows a 2-state Markov process:

$$
\pi\left(A^{\prime} \mid A\right)=\operatorname{Prob}\left\{A_{t+1}=A^{\prime} \mid A_{t}=A\right\}=\left(\begin{array}{cc}
\pi_{11}^{A} & \pi_{12}^{A} \\
\pi_{21}^{A} & \pi_{22}^{A}
\end{array}\right) .
$$

In a factor market equilibrium, factors are rewarded with their marginal product:

$$
\begin{aligned}
w_{t} & =(1-\alpha) A_{t} K_{t}^{\alpha} N_{t}^{-\alpha} \\
r_{t} & =\alpha A_{t} K_{t}^{\alpha-1} N_{t}^{1-\alpha}-\delta .
\end{aligned}
$$

Capital $K$ depreciates at rate $\delta$.

\subsection{Government}

The government provides pensions to the retired agents. Pensions are proportional to the current-period wage rate with the replacement ratio being denoted by $\zeta$. In addition, we distinguish the two cases that pensions are either lump-sum or depend on the permanent efficiency type $\epsilon$ :

$$
b_{t}= \begin{cases}\zeta w_{t} \bar{n} & \text { lump-sum } \\ \zeta \epsilon w_{t} \bar{n} & \text { efficiency-dependent }\end{cases}
$$

$\bar{n}$ denotes the average labor supply in the economy in the non-stochastic steady state (with $A \equiv 1)$. Therefore, pensions of the retired agents do not increase if the contemporary workers increase their labor supply. 


\subsection{Stationary equilibrium}

In the stationary equilibrium, individual behavior is consistent with the aggregate behavior of the economy, households maximize intertemporal utility, firms maximize profits, and factor and goods' markets are in equilibrium. Let $f_{t}(k, s, \epsilon, z)$ denote the distribution of individual wealth $k$, age $s$, the efficiency type $\epsilon$, and idiosyncratic productivity $z$ in the period $t$.

A stationary equilibrium for a government policy $\{\zeta\}$ and initial measures $f_{0}(k, s, \epsilon, z)$ in period 0 corresponds to a price system, an allocation, and a sequence of aggregate productivity indicators $\left\{A_{t}\right\}$ that satisfy the following conditions:

1. Households maximize the intertemporal utility (1) subject to the budget constraint (3) or (4), and the dynamics of the idiosyncratic productivity level $z,(11)$. This gives rise to the following first-order conditions:

$$
\begin{aligned}
\frac{1-\gamma}{\gamma} \frac{c_{t}^{s}}{1-n_{t}^{s}} & =\left(1-\tau_{w, t}\right) w_{t} e(s, \epsilon, z), \\
\left(c_{t}^{s}\right)^{\gamma(1-\sigma)-1}\left(1-n_{t}^{s}\right)^{(1-\gamma)(1-\sigma)} & =\beta E_{t}\left\{\left[1+r_{t+1}\right]\left(c_{t+1}^{s+1}\right)^{\gamma(1-\sigma)-1}\left(1-n_{t+1}^{s+1}\right)^{(1-\gamma)(1-\sigma)}\right\} .
\end{aligned}
$$

Individual labor supply $n_{t}(k, s, \epsilon, z)$, consumption $c_{t}(k, s, \epsilon, z)$, and optimal next period capital stock $k_{t}^{\prime}(k, s, \epsilon, z)$ in period $t$ are functions of the individual state variables $\{k, s, \epsilon, z\}$ and also depend on the period $t$.

2. Firms maximize profits satisfying (7) and (8).

3. Aggregate variables are equal to the sum of the individual variables:

$$
\begin{aligned}
N_{t} & =\sum_{s=1}^{45} \sum_{\epsilon, z} \int_{k} e(s, \epsilon, z) n_{t}(k, s, \epsilon, z) f_{t}(k, s, \epsilon, z) d k \\
K_{t} & =\sum_{s=1}^{70} \sum_{\epsilon, z} \int_{k} k f_{t}(k, s, \epsilon, z) d k \\
C_{t} & =\sum_{s=1}^{70} \sum_{\epsilon, z} \int_{k} c_{t}(k, s, \epsilon, z) f_{t}(k, s, \epsilon, z) d k \\
B_{t} & =\sum_{s=46}^{70} \sum_{\epsilon, z} \int_{k} b_{t}(\epsilon) f_{t}(k, s, \epsilon, z) d k
\end{aligned}
$$

where $C_{t}$ and $B_{t}$ denote aggregate consumption and pensions, respectively. 
4. The government budget is balanced:

$$
B_{t}=\tau_{w, t} w_{t} N_{t}
$$

In particular, the contribution rate $\tau_{w, t}$ adjusts in each period.

5. The goods' market clears:

$$
C_{t}+K_{t+1}-(1-\delta) K_{t}=Y_{t}
$$

6. The cross-sectional measure $f_{t}$ evolves as

$$
f_{t+1}(\mathcal{K} \times \mathcal{S} \times \mathcal{E} \times \mathcal{Z})=\int \sum_{s, \epsilon, z} P_{t}((k, s, \epsilon, z), \mathcal{K} \times \mathcal{S} \times \mathcal{E} \times \mathcal{Z}) f_{t}(k, s, \epsilon, z) d k
$$

with

$$
P_{t}((k, s, \epsilon, z), \mathcal{K} \times \mathcal{S} \times \mathcal{E} \times \mathcal{Z})= \begin{cases}\sum_{z^{\prime} \in \mathcal{Z}} \pi\left(z^{\prime} \mid z\right) & \text { if } k_{t}^{\prime}(k, s, \epsilon, z) \in \mathcal{K} \\ & \epsilon \in \mathcal{E}, s+1 \in \mathcal{S} \\ 0 & \text { else }\end{cases}
$$

and for the newborns

$$
f_{t+1}(\mathcal{K} \times 1 \times \mathcal{E} \times \mathcal{Z})= \begin{cases}\sum_{\epsilon \in \mathcal{E}, z \in \mathcal{Z}} \frac{1}{4 \cdot 70} & \text { if } 0 \in \mathcal{K} \\ 0 & \text { else }\end{cases}
$$

\subsection{Calibration and computation}

We choose the parameter values $\beta=0.99, \eta=2.0, \gamma=0.28, \alpha=0.35, \delta=0.08$ that are standard in the business cycle literature. ${ }^{2}$ The Markov process (6) of aggregate technology level is calibrated so that the average duration of one cycle is equal to 6 years:

$$
\pi\left(A^{\prime} \mid A\right)=\left(\begin{array}{ll}
2 / 3 & 1 / 3 \\
1 / 3 & 2 / 3
\end{array}\right)
$$

Aggregate technology is chosen so that the mean $\bar{A}$ is equal to one and the annual standard deviation of output is approximately equal to $2 \%$ implying $\left\{A_{1}, A_{2}\right\}=\{0.98,1.02\}$.

\footnotetext{
${ }^{2}$ See, for example, Heer and Maussner (2005).
} 
The calibration of the individual productivity $e(s, \epsilon, z)$ is chosen in accordance with Krueger and Ludwig (2007). In particular, we pick $\left\{\epsilon_{1}, \epsilon_{2}\right\}=\{0.57,1.43\}$ so that the average productivity is one and the implied variance of labor income for the new entrants at age $s=1$ is equal to the value reported by Storesletten et al. (2004). The annual persistence of the idiosyncratic component $z$ is chosen to be 0.98 . In addition, idiosyncratic productivity has a conditional variance of $8 \%$, implying $\left\{z_{1}, z_{2}\right\}=\{0.727,1.273\}$, and

$$
\pi\left(z^{\prime} \mid z\right)=\left(\begin{array}{cc}
0.98 & 0.02 \\
0.02 & 0.98
\end{array}\right)
$$

The age-efficiency $\bar{y}_{s}$ profile is taken from Hansen (1993). The calibration implies an average labor supply approximately equal to $\bar{n}=0.3$ and a Gini coefficient of income (wealth) equal to 0.42 (0.58) in good accordance with empirical observations, even though the values are lower than those of most recent studies on the empirical wealth and income distribution. In particular, for the US economy, Rodriguez et al. (2002) find a value of 0.55 (0.80) for the income Gini (wealth Gini). ${ }^{3}$

The replacement ratio of average pensions relative to net wage earnings is equal to $\zeta=$ $\frac{\bar{b}_{t}}{\left(1-\tau_{w, t}\right) w_{t} \bar{n}}=30 \%$, with $\bar{n}=0.3$.

The computation is based upon the algorithm of Krusell and Smith (1998) and follows Storesletten et al. (2004). A detailed description is provided in the Appendix.

\section{Results}

Figure 1 describes the behavior of our economy in the non-stochastic steady state. In the upper row, we graph the average wealth and labor supply of each generaton, while the average total income of each generation and the efficiency-age profiles $e(s, \epsilon, z)$ for the four productivity types $\left\{\epsilon_{i}, z_{j}\right\}$ for $i=1,2, j=1,2$, are displayed in the lower row. Agents accumulate savings until retirement age $s=45$ (corresponding to real lifetime age 65 in the Figure 1) and dissave thereafter. Total income (wage plus interest income before taxes) peaks at real lifetime age 50. Our average-age profiles accord very well with empirical observations in Rodriguez et al. (2002). Based on the 1998 data from the Survey of Consumer Finances they find that US household income, earnings, and wealth peak around ages 51-55, 51-55, and 61-65, respectively.

In order to compute the correlation of the income distribution with output, we simulate the dynamics of our economy repeatedly over 200 periods. One of these simulations is

\footnotetext{
${ }^{3}$ In order to get an even better match of the model and empirical Gini coefficients, we should introduce entrepreneuership into the model as, for example, in Quadrini (2000). However, we kept the model as simple as possible in order to illustrate the main effects.
} 
Figure 1: Non-stochastic steady state age-profiles
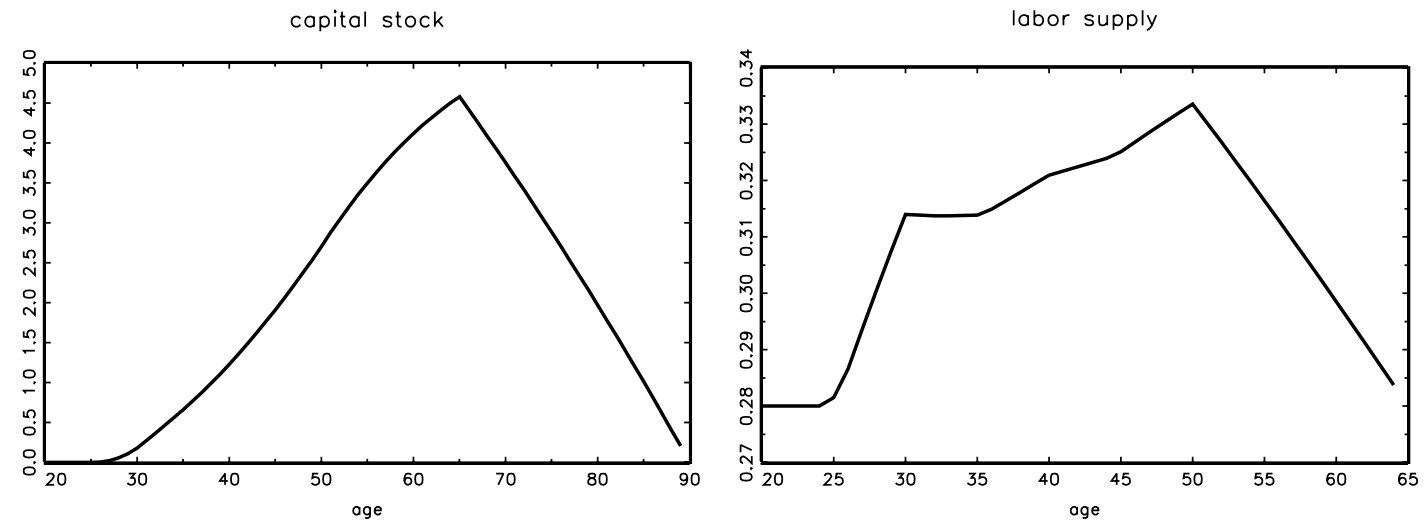

total income
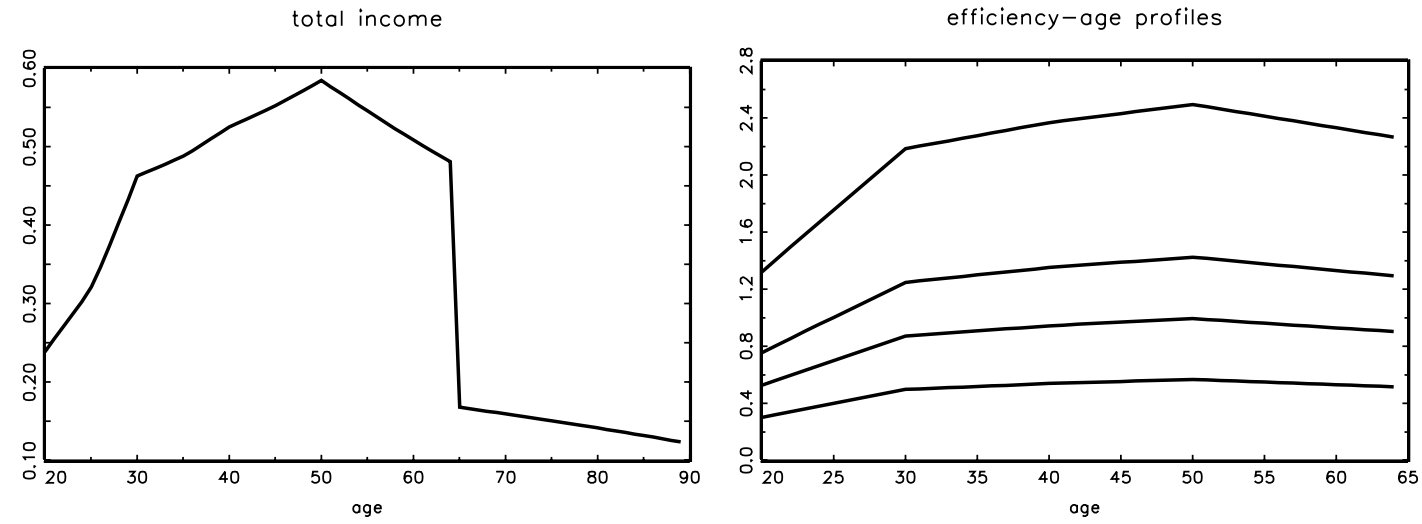

illustrated in Figure 2. In the lower picture, we graph the dynamics of output. ${ }^{4}$ If the technology level jumps from $A_{1}$ to $A_{2}$ or vice versa, this is also instantaneously reflected in the movement of the production level. In the upper picture, we graph the behavior of the Gini coefficient of total income. Obviously, total income is highly procyclical. The correlation coefficient of the total income Gini coefficient with output amounts to 0.87 . As a simple explanation, the high-productivity workers increase their labor supply by a higher percentage than the low-productivity workers when the wage rates increases during an economic expansion.

Table 1 takes a detailed look at the behavior of the income quintiles. In the first entry row, we display the empirical correlations of output with the 1st, $2 \mathrm{nd}$, 3rd, and 4 th income quintiles, and the 80-95\% and 95-100\% income groups for the US economy, respectively. ${ }^{5}$ In the second row, you find the values as resulting from the simulation of the most preferred model of Castañeda et al. (1998). The last two lines display the values obtained from simulating our economy for the two cases that pensions are either proportional to the

\footnotetext{
${ }^{4}$ Logarithmic output has been detrended using the Hodrick-Prescott filter with smoothing parameter $\lambda=100$.

${ }^{5}$ The estimates are reproduced from Table 4 in Castañeda et al. (1998).
} 
Figure 2: Time series simulation

Gini total income

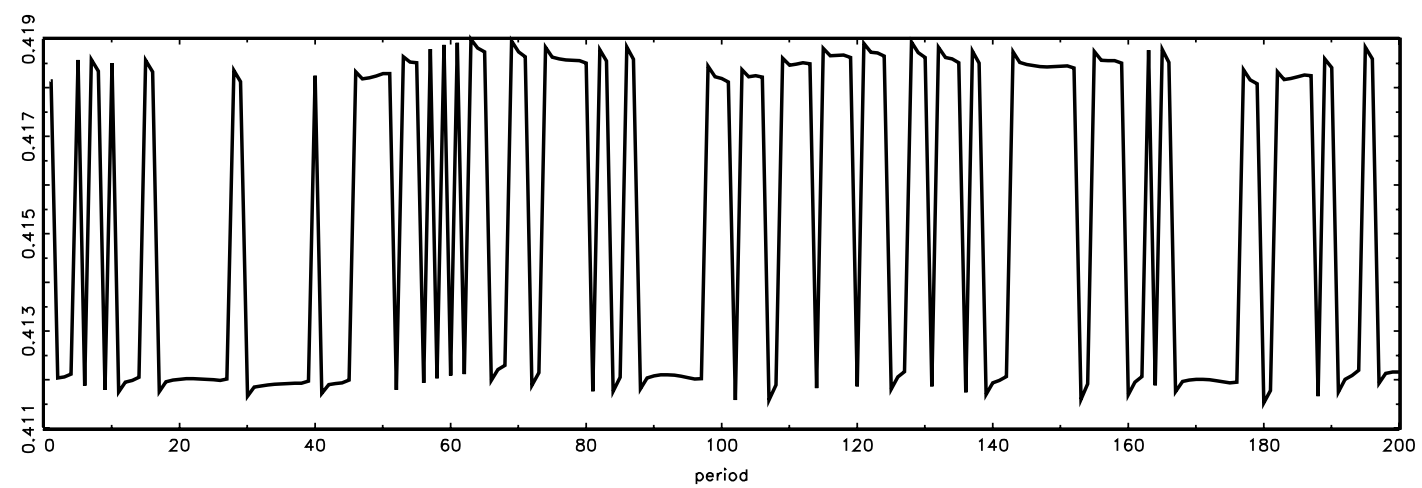

HP-detrended output

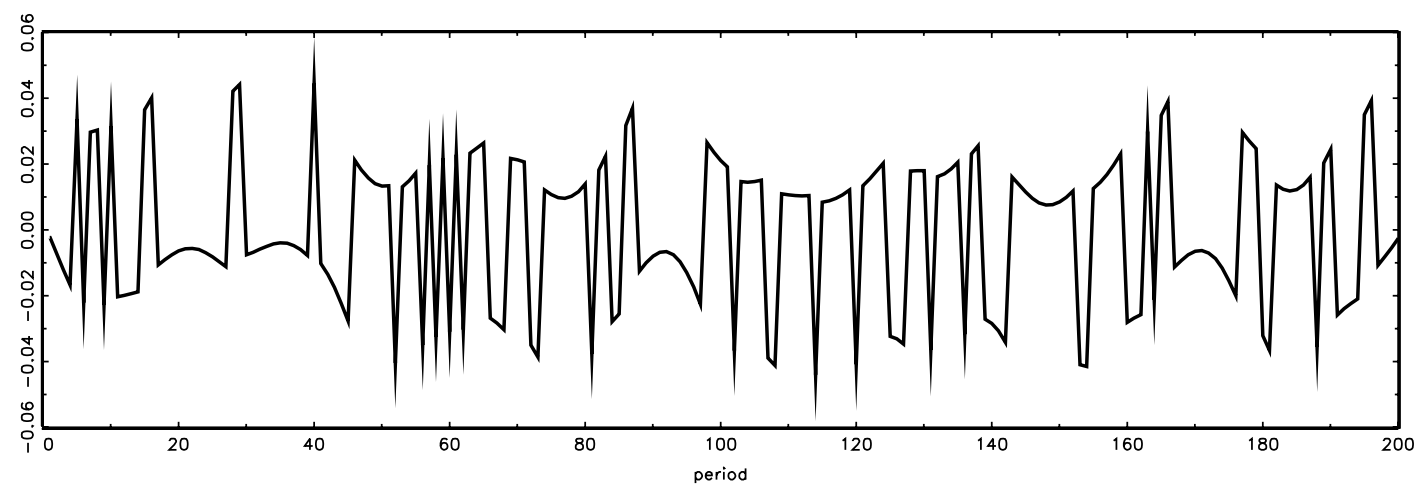

individual efficiency $\epsilon$ or lump-sum. Obviously, the model with lump-sum pensions is our preferred model (last row). In this case, the income share of the first and fourth income quintile and the top $5 \%$ group match the empirical correlations almost perfectly, while the correlations of the 2nd and 3rd income quintiles with output are too low.

In our model, the dynamics of the income distribution are mainly driven by the intertemporal substitution of labor. During an economic expansion, wages increase and labor (replacement) income is redistributed 1) from low-productivity to high productivity workers, 2) old wealth-rich to young wealth-poor workers, and 3) retired agents to working agents as the former groups increase their labor supply to a larger extent than the latter, respectively. In our economy with overlapping generations, the highest income quintile consists of the workers aged 50-60 with high productivity as these agents have the highest wage income and relatively high interest income. As these agents also hold relatively high wealth, they do not increase their labor supply as much as the younger high-productivity workers. As a consequence, the total income share of the top 5\% income earners is almost acyclical.

The lowest income quintile in our economy consists of the very old retired workers (aged 
Table 1: Correlation of output with income shares

\begin{tabular}{l|cccccc} 
& $0-20 \%$ & $20-40 \%$ & $40-60 \%$ & $60-80 \%$ & $80-95 \%$ & $95-100 \%$ \\
\hline \hline US & 0.53 & 0.49 & 0.31 & -0.29 & -0.64 & 0.00 \\
\hline Castañeda et al. (1998) & 0.95 & 0.92 & 0.73 & -0.56 & -0.90 & -0.84 \\
\hline & & & & & & \\
our model & & & & & & \\
i) $b_{t}(\epsilon)=\epsilon \bar{b}_{t}$ & -0.15 & -0.07 & -0.08 & -0.01 & 0.31 & 0.03 \\
ii) $b_{t}(\epsilon)=\bar{b}_{t}$ & 0.40 & -0.47 & -0.11 & -0.24 & 0.60 & 0.04 \\
\hline
\end{tabular}

Notes: Entries in rows 1 and 2 are reproduced from Table 4 in Castañeda et al. (1998). Annual logarithmic output has been detrended using the Hodrick-Prescott filter with smoothing parameter $\lambda=100$.

80 and above) and the young workers with low productivity $\epsilon_{1}$ and $z_{1}$ (aged 20-30). Since the pension income falls relative to the wage income during an economic expansion, the correlation of output with the income share of the first quintile is not close to unity as in Castañeda et al. (1998). Therefore, the introduction of overlapping generations, pensions, and elastic labor helps to improve upon the modeling of the income distribution business cycles dynamics. In fact, in our model, the correlations of the first and second income quintiles with output are even a little bit too low compared to empirical observations. The latter deficiency of our model, of course, could be improved by the introduction of unemployment risk so that the number of employed workers in the lowest income quintiles becomes more procyclical again.

\section{Conclusion}

Previous work by Castañeda et al. (1998) has been very successful to model the business cycle dynamics of the different income quintiles except for the top $5 \%$ group. In addition, the lower income quintiles very almost perfectly correlated with output which is at odds with empirical observations for the US economy. We presented a model with overlapping generations, pensions, and elastic labor that helps to overcome these deficiencies. We therefore conclude that a business cycle model of the income distribution should be a hybrid model including both the risk of unemployment and overlapping generations with elastic labor supply. 


\section{References}

Castañeda, A., J. Díaz-Giminénez, J.-V. Ríos-Rull, 1998, Exploring the income distribution business cycle dynamics, Journal of Monetary Economics, vol. 42, 93-130.

Hansen, G., 1993, The cyclical and secular behavior of the labor input: comparing efficiency units and hours worked, Journal of Applied Econometrics 8, 71-80.

Heer, B., and A. Maussner, 2005, Dynamic General Equilibrium models: Computational Methods and Applications, Springer-Verlag, Berlin.

Heer, B., and A. Maussner, 2007, The Burden of Unanticpated Inflation: Analysis of an Overlapping Generations Model with Progressive Income Taxation and Staggered Prices, mimeo.

Krueger, D., and A. Ludwig, 2007, On the Consequences of Demographic Change for Rates of Returns to Capital, and the Distribution of Wealth and Welfare, Journal of Monetary Economics, forthcoming.

Krusell, P., and A. Smith, 1998, Income and Wealth Heterogeneity in the Macroeconomy, Journal of Political Economy, vol. 106, 867-96.

Quadrini, V., 2000, Entrepreneurship, Saving and Social Mobility, Review of Economic Dynamics, vol. 3, 1-40.

Rodriguez, S.B., J. Díaz-Giménez, V. Quadrini, and J.V. Ríos-Rull, 2002, Updated Facts on the U.S. Distributions of Earnings, Income, and Wealth, Federal Reserve Bank of Minneapolis Quarterly Review, vol. 26, 2-35.

Storesletten, K., C.I. Telmer, and A. Yaron, 2004, Asset pricing with idiosyncratic risk and overlapping generations, mimeo. 


\section{Appendix: Computation of the model}

In order to compute the model of Section 2, we use the algorithm of Krusell and Smith (1998). This algorithm has been applied to overlapping generations models by Storesletten et al. (2004), among others. Our computation follows common practice in this literature and is described by the following steps:

\section{Algorithm: Computation of the OLG model with individual and aggregate uncertainty}

Step 1: Compute the non-stochastic steady state with $A \equiv 1$. Store the policy functions and the steady-state distribution of $\{k, s, \epsilon, z\}$.

Step 2: Choose an initial parameterized functional form for the law of motion for the aggregate next-period capital stock $K^{\prime}=g(K, A)$ and employment $N^{\prime}=h\left(K^{\prime}, A^{\prime}\right)$.

Step 3: Solve the consumer's optimization problem as a function of the individual and aggregate state variables, $\{k, s, \epsilon, z ; K, A\}$.

Step 4: Simulate the dynamics of the distribution function.

Step 5: Use the time path for the distribution to estimate the law of motion for $K^{\prime}$ and $N^{\prime}$.

Step 6: Iterate until the parameters converge.

Step 7: Test the goodness of fit for the functional form using, for example, $R^{2}$. If the fit is satisfactory, stop, otherwise choose a different functional form for $g($.$) and/or h($.$) .$

In the first step, the non-stochastic steady state allocation is computed with standard methods. In particular, we discretize the individual state space using a grid over the individual asset space $k$ of 50 points and interpolate linearly between points. The policy functions $k^{\prime}(k, s, \epsilon, z)$ and $n(k, s, \epsilon, z)$ are computed from the first-order conditions of the household starting in the last period of life, $s=90$. Special care has to be taken of the corner solutions with $n=0$ and $k^{\prime}=0 .{ }^{6}$ The optimal policy functions are stored in order to use them as an initial guess for the policy functions in step 3. Similarly, we save the non-stochastic steady state distribution and use it as initial distribution for the simulation of the stochastic economy in step 4 .

\footnotetext{
${ }^{6}$ In addition, we use our own routine for the solution of non-linear equations that is able to handle returns in the form of missing values if, for example, consumption is negative and utility is not defined. For details, please see Chapters 7 and 8 in Heer and Maussner (2005).
} 
In the second step, we postulate the following laws of motion for the next-period capital stock and employment:

$$
\begin{aligned}
& K^{\prime}=\exp \left(\theta_{0}+\theta_{1} \ln (K)+\theta_{2} \mathbf{1}_{A^{\prime}=A_{1}}+\theta_{3} \mathbf{1}_{A^{\prime}=A_{1}} \ln (K)\right) \\
& N^{\prime}=\exp \left(\kappa_{0}+\kappa_{1} \ln \left(K^{\prime}\right)+\kappa_{2} \mathbf{1}_{A^{\prime}=A_{1}}+\kappa_{3} \mathbf{1}_{A^{\prime}=A_{1}} \ln \left(K^{\prime}\right)\right)
\end{aligned}
$$

Notice in particular that next-period employment is a function of next-period capital stock $K^{\prime}$ and next-period aggregate productivity $A^{\prime}$ only. Therefore, employment $N$ is not an aggregate state variable. As an initialization, we set $\theta_{2}=\theta_{3}=\kappa_{1}=\kappa_{2}=\kappa_{3}=0$. We choose $\theta_{1}=0.9$ and compute $\theta_{0}$ and $\kappa_{0}$ so that $K^{\prime}=K$ and $N^{\prime}=N$ correspond to their non-stochastic steady state values, respectively.

As our solution, we find the following laws of motion:

$$
\begin{aligned}
& K^{\prime}=\exp \left(0.0610+0.0126 \ln (K)+0.9076 \mathbf{1}_{A^{\prime}=A_{1}}-0.0043 \mathbf{1}_{A^{\prime}=A_{1}} \ln (K)\right), \\
& N^{\prime}=\exp \left(-1.265+0.0179 \ln \left(K^{\prime}\right)-0.1751 \mathbf{1}_{A^{\prime}=A_{1}}+0.0064 \mathbf{1}_{A^{\prime}=A_{1}} \ln \left(K^{\prime}\right)\right) .
\end{aligned}
$$

In step 3, we compute the individual policy function as functions of the individual and aggregate state variables for given law of motion for $K^{\prime}$ and $N^{\prime}$. For this reason, we choose a rather loose grid for the aggregate capital stock $K$ as the curvature of the policy function with respect to this argument is rather low. We find that 7 points are sufficient. Furthermore, we choose $80 \%$ and $120 \%$ of the non-stochastic steady state aggregate capital stock as the lower and upper boundary for this interval. In our simulations, the aggregate capital stock always remains within these boundaries.

Starting with the non-stochastic steady state distribution as our initial distribution $f_{0}(k, s, \epsilon, z)$, we simulate the dynamics of the economy. We use a pseudo-random number generator in order to simulate the economy over 200 periods repeatedly. Given the distribution in period $t, f_{t}(k, s, \epsilon, z)$, we can compute the next-period distribution, $f_{t+1}(k, s, \epsilon, z)$, with the help of the policy functions $k^{\prime}(k, s, \epsilon, z ; K, A)$ and $n(k, s, \epsilon, z ; K, A)$. In addition, we can compute aggregate production and the income shares of the different quintiles. For a more detailed description of this step, please see Heer and Maussner (2005), Chapter 6.

We update the parameters by estimating the law of motions for the simulated time series with the help of OLS. We stop the algorithm as soon as the maximum change of the $\theta_{i}$ and $\kappa_{j}$ is below 0.001. In our last iteration, the $R^{2}$ in the two regressions of the law of motion exceeds 0.999 , respectively. Therefore, we can be confident that our postulated laws of motion $g($.$) and h($.$) are satisfactory. The computation takes some 20$ hours on a Intel Pentium(R) M, $319 \mathrm{MHz}$ machine. The computer programs are available from the author upon request. 


\section{CESifo Working Paper Series}

(for full list see www.cesifo-group.de)

1884 Johannes Becker and Clemens Fuest, Corporate Tax Policy and International Mergers and Acquisitions - Is the Tax Exemption System Superior?, January 2007

1885 Momi Dahan and Udi Nisan, The Effect of Benefits Level on Take-up Rates: Evidence from a Natural Experiment, January 2007

1886 José García-Solanes, Francisco I. Sancho-Portero and Fernando Torrejón-Flores, Beyond the Salassa-Samuelson Effect in some New Member States of the European Union, January 2007

1887 Peter Egger, Wolfgang Eggert and Hannes Winner, Saving Taxes Through Foreign Plant Ownership, January 2007

1888 Timothy J. Goodspeed and Andrew Haughwout, On the Optimal Design of Disaster Insurance in a Federation, January 2007

1889 Wim Groot, Henriëtte Maassen van den Brink and Bernard van Praag, The Compensating Income Variation of Social Capital, January 2007

1890 Bas Jacobs, Ruud A. de Mooij and Kees Folmer, Analyzing a Flat Income Tax in the Netherlands, January 2007

1891 Hans Jarle Kind, Guttorm Schjelderup and Frank Stähler, Newspapers and Advertising: The Effects of Ad-Valorem Taxation under Duopoly, January 2007

1892 Erkki Koskela and Rune Stenbacka, Equilibrium Unemployment with Outsourcing under Labour Market Imperfections, January 2007

1893 Maarten Bosker, Steven Brakman, Harry Garretsen, Herman de Jong and Marc Schramm, The Development of Cities in Italy 1300 - 1861, January 2007

1894 Michel Beine, Oscar Bernal, Jean-Yves Gnabo and Christelle Lecourt, Intervention Policy of the BoJ: A Unified Approach, January 2007

1895 Robert S. Chirinko and Daniel J. Wilson, State Investment Tax Incentives: A Zero-Sum Game?, January 2007

1896 Theo S. Eicher and Oliver Roehn, Sources of the German Productivity Demise Tracing the Effects of Industry-Level ICT Investment, January 2007

1897 Helge Berger, Volker Nitsch and Tonny Lybek, Central Bank Boards around the World: Why does Membership Size Differ?, January 2007

1898 Gabriel Felbermayr and Wilhelm Kohler, Does WTO Membership Make a Difference at the Extensive Margin of World Trade?, January 2007 
1899 Benno Torgler and Friedrich Schneider, The Impact of Tax Morale and Institutional Quality on the Shadow Economy, January 2007

1900 Tomer Blumkin and Efraim Sadka, On the Desirability of Taxing Charitable Contributions, January 2007

1901 Frederick van der Ploeg and Reinhilde Veugelers, Higher Education Reform and the Renewed Lisbon Strategy: Role of Member States and the European Commission, January 2007

1902 John Lewis, Hitting and Hoping? Meeting the Exchange Rate and Inflation Criteria during a Period of Nominal Convergence, January 2007

1903 Torben M. Andersen, The Scandinavian Model - Prospects and Challenges, January 2007

1904 Stephane Dees, Sean Holly, M. Hashem Pesaran and L. Vanessa Smith, Long Run Macroeconomic Relations in the Global Economy, January 2007

1905 Richard Jong-A-Pin and Jakob De Haan, Political Regime Change, Economic Reform and Growth Accelerations, January 2007

1906 Sascha O. Becker and Peter H. Egger, Endogenous Product versus Process Innovation and a Firm's Propensity to Export, February 2007

1907 Theo S. Eicher, Chris Papageorgiou and Oliver Roehn, Unraveling the Fortunates of the Fortunate: An Iterative Bayesian Model Averaging (IBMA) Approach, February 2007

1908 Liliana E. Pezzin, Robert A. Pollak and Barbara S. Schone, Efficiency in Family Bargaining: Living Arrangements and Caregiving Decisions of Adult Children and Disabled Elderly Parents, February 2007

1909 Christian Keuschnigg and Soren Bo Nielsen, Self-Selection and Advice in Venture Capital Finance, February 2007

1910 Rune Jansen Hagen and Gaute Torsvik, Irreversible Investments, Dynamic Inconsistency and Policy Convergence, February 2007

1911 Eric A. Hanushek and Ludger Woessmann, The Role of School Improvement in Economic Development, February 2007

1912 Bernard M. S. van Praag, Perspectives from the Happiness Literature and the Role of New Instruments for Policy Analysis, February 2007

1913 Volker Grossmann and Thomas M. Steger, Growth, Development, and Technological Change, February 2007

1914 Margarita Katsimi and Thomas Moutos, Human Capital and the Feldstein-Horioka Puzzle, February 2007 
1915 Oliver Roehn, Theo S. Eicher and Thomas Strobel, The Ifo Industry Growth Accounting Database, February 2007

1916 Ian Babetskii, Aggregate Wage Flexibility in Selected New EU Member States, February 2007

1917 Burkhard Heer, Alfred Maussner and Paul D. McNelis, The Money-Age Distribution: Empirical Facts and Limited Monetary Models, February 2007

1918 Yin-Wong Cheung, Menzie D. Chinn and Eijii Fujii, The Overvaluation of Renminbi Undervaluation, February 2007

1919 Jim Malley, Apostolis Philippopoulos and Ulrich Woitek, To React or Not? Fiscal Policy, Volatility and Welfare in the EU-3, February 2007

1920 Mattias Polborn, Competing for Recognition through Public Good Provision, February 2007

1921 Lars P. Feld and Benno Torgler, Tax Morale after the Reunification of Germany: Results from a Quasi-Natural Experiment, February 2007

1922 Robert S. Chirinko and Huntley Schaller, Fundamentals, Misvaluation, and Investment: The Real Story, February 2007

1923 Benno Torgler and Friedrich Schneider, Shadow Economy, Tax Morale, Governance and Institutional Quality: A Panel Analysis, February 2007

1924 Adrian Pagan and M. Hashem Pesaran, On Econometric Analysis of Structural Systems with Permanent and Transitory Shocks and Exogenous Variables, February 2007

1925 Hans-Werner Sinn, The Welfare State and the Forces of Globalization, February 2007

1926 Michael Smart, Raising Taxes through Equalization, February 2007

1927 Øystein Foros, Kåre P. Hagen and Hans Jarle Kind, Price-Dependent Profit Sharing as an Escape from the Bertrand Paradox, February 2007

1928 Balázs Égert, Kirsten Lommatzsch and Amina Lahrèche-Révil, Real Exchange Rates in Small Open OECD and Transition Economies: Comparing Apples with Oranges?, February 2007

1929 Aleksander Berentsen and Cyril Monnet, Monetary Policy in a Channel System, February 2007

1930 Wolfgang Ochel, The Free Movement of Inactive Citizens in the EU - A Challenge for the European Welfare State?, February 2007

1931 James K. Hammitt and Nicolas Treich, Statistical vs. Identified Lives in Benefit-Cost Analysis, February 2007 
1932 Wilhelm Kohler, The Bazaar Effect, Unbundling of Comparative Advantage, and Migration, February 2007

1933 Karsten Staehr, Fiscal Policies and Business Cycles in an Enlarged Euro Area, February 2007

1934 Michele Bernasconi and Paola Profeta, Redistribution or Education? The Political Economy of the Social Race, March 2007

1935 Axel Dreher, Martin Gassebner and Lars-H. R. Siemers, Does Terror Threaten Human Rights? Evidence from Panel Data, March 2007

1936 Naércio Aquino Menezes Filho and Marc-Andreas Muendler, Labor Reallocation in Response to Trade Reform, March 2007

1937 Gebhard Flaig and Timo Wollmershaeuser, Does the Euro-zone Diverge? A Stress Indicator for Analyzing Trends and Cycles in Real GDP and Inflation, March 2007

1938 Michael Funke and Michael Paetz, Environmental Policy Under Model Uncertainty: A Robust Optimal Control Approach, March 2007

1939 Byeongchan Seong, Sung K. Ahn and Peter A. Zadrozny, Cointegration Analysis with Mixed-Frequency Data, March 2007

1940 Monika Bütler and Michel André Maréchal, Framing Effects in Political Decision Making: Evidence from a Natural Voting Experiment, March 2007

1941 Giacomo Corneo and Olivier Jeanne, A Theory of Tolerance, March 2007

1942 Qing Hong and Michael Smart, In Praise of Tax Havens: International Tax Planning and Foreign Direct Investment, March 2007

1943 Yin-Wong Cheung, Dickson Tam and Matthew S. Yiu, Does the Chinese Interest Rate Follow the US Interest Rate?, March 2007

1944 Panu Poutvaara and Mikael Priks, Unemployment and Gang Crime: Could Prosperity Backfire?, March 2007

1945 Burkhard Heer, On the Modeling of the Income Distribution Business Cycle Dynamics, March 2007 